\title{
BAILBONDSMEN AND THE FUGITIVE ACCUSED-THE NEED FOR FORMAL REMOVAL PROCEDURES
}

THE powers of the private bail bondsman to arrest and remove fugitive criminals from one state to another seem anachronistic in the context of the careful safeguards developed to protect the criminal accused in formal extradition procedure. A state, demanding return of an accused from another state (the asylum state) is required to comply with formal remittance procedures, sanctioned both by statute and by Constitution. ${ }^{1}$ Demanding state officials are powerless to arrest and transport an accused criminal apprehended in a foreign jurisdiction from that jurisdiction to their own $;^{2}$ in requesting extradition, demanding states are required by the federal extradition act to comply with certain formalities. ${ }^{3}$ And under the Uniform Criminal Extradition Act, ${ }^{4}$ currently in force in forty-four states, any accused arrested in an asylum jurisdiction prior to requisition must be placed in custody of officials of that jurisdiction, pending receipt of a demand in compliance with the federal and state acts. ${ }^{5}$ The accused must immediately be presented before a magistrate

1. See Fitzpatrick v. Williams, 46 F.2d 40, 41-42 (5th Cir. 1931).

2. Spears, The Law of Extradition 346-47 (1879); see generally Note, 61 Yale L.J. 445 (1952).

3. 18 U.S.C. $\S 3182$ (1958). The details of extradition procedure are governed by both federal and state legislation. The federal statute was adopted by Congress in 1793 in order to implement the constitutional mandate that a "person charged in any state with treason, felony or other crime, who shall flee from justice, and be found in another state, shall on demand of the executive authority of the state from which he fled be delivered up to be removed to the state having jurisdiction of the crime." U.S. CoNsT. art. IV, $§ 2$. The federal statute, which has remained substantially unchanged since its passage, provides that on proper demand it is the duty of the "executive authority" of the asylum state to detain the accused, and turn him over to the agent of the executive authority of the demanding state. 18 U.S.C. $\$ 3182$ (1958). The demand must include a copy of an indictment found or an affidavit made by a magistrate, and certified as authentic by the governor of the demanding state, charging the defendant with a crime. The person demanded must be a "fugitive from justice," i.e., must have been in the demanding state at the time of the alleged crime, and must presently be sought to answer for the crime in the courts of the demanding state. See Ex parte Riccardi, 68 Ariz. 180, 203 P.2d 627 (1949).

4. 9 UNIFoRn LAwS ANN. [hereinafter cited as U.L.A.] 174 (1951).

Because the federal statute does not cover all the situations which may arise, it has been acknowledged that the state may provide machinery for applying the law of extradition in respect to matters not covered by Congress, including the method of arrest and detention before extradition is demanded, the method of applying for a writ of habeas corpus, the mode of preliminary trial and the manner of applying for a requisition. See Commissioner's note to Uniform CrImINal Extradition ACT 9 U.L.A. 171 (1951). A considerable degree of uniformity in these particulars has been achieved through the widespread adoption of the Uniforar Criminal Extradition Act. Besides the additions mentioned above, the uniform statute reaffirms the federal requirements relating to the form of the demand and makes explicit provision for the return of defendants who have fled after conviction. UnIFORM CRIMINAI ExTRADITION ACT $\$ 3$.

5. See Uniform Criminal Extradition ACt $\S$ 10,11, 13, 14. No doubt officers from the demanding state qualify as "credible persons" or persons providing "reasonable information" within the meaning of sections 13 and 14. 
who must inform him of his right to retain counsel to assist him in contesting the formal sufficiency of the demand. ${ }^{6}$ Within a short time after commitment, the demanding state must present a formal requisition to the asylum state, or the accused may be released. ${ }^{7}$ To comply with the federal and state legislation, this request must include sworn documents indicating, inter alia, that the accused was in the demanding jurisdiction at the time the alleged crime was committed, ${ }^{8}$ and that there is colorable proof that the accused had committed acts ${ }^{0}$ which constitute crimes ${ }^{10}$ under the laws of the demanding jurisdiction - acts for which he stands charged or convicted. ${ }^{11}$ The sufficiency of

6. Under $\$ 10$ of the UNIFORA Acr, the magistrate or judge is explicitly directed to inform the accused of his right to procure legal counsel and to challenge his arrest by seeking a writ of habeas corpus. But $\$ 10$ only covers accused persons who have been arrested upon a rendition warrant issued by the governor of the asylum state. Where the accused is arrested "on the oath of any credible person" prior to issuance of such a warrant, for detention pending receipt of a demand from the governor of the demanding state, $\S 13$ requires only that the accused first be brought before a judge or magistrate to "answer the charge" that he is an extraditable fugitive from justice.

7. See UnIformi Criminal Extradition Act $\$ \$ 15,17$.

3. See Uniform Criminnal Extradition Act $\$ 3$; Huff v. Ayers, 6 N.J. Super. 380, 71 A.2d 392 (1950). Section 6 of the UNIFORM ACT permits exceptions in the unusual case when acts committed in one state cause crimes in another state.

9. Section 3 of the UNIFORM AcT requires the demand for extradition be accompanied by:

... a copy of an indictment found or ... [an] information supported by affidavit in the state having jurisdiction of the crime, or by a copy of an affidavit made before a magistrate there, together with a copy of any warrant which was issued thereupon; or by a copy of a judgment of conviction or of a sentence imposed in execution thereof, together with a statement by the Executive Authority of the demanding state that the person claimed has escaped from confinement or has broken the terms of his bail, probation or parole. The indictment, information, or affidavit made before the magistrate must substantially charge the person demanded with having committed a crime under the laws of that state. . .

In United States v. Meyering, 75 F.2d 716 (7th Cir. 1935), a leading case, the court, on appeal from a habeas corpus proceeding, ordered that the fugitive, who had fled before trial for murder, be discharged from the custody of the asylum state because a requisition issued by the demanding governor did not contain a copy of an indictment or a certified affidavit upon which a finding of probable cause might be found. The affidavit was defective because it mentioned facts which could have been known only to an eye witness, but included no statement by the affiant that she was, in fact, present, or that she had reasonable grounds to believe that the alleged acts occurred. Again, in Henry v. McArthur, 122 Colo. 474, 223 P.2d 621 (1950), the prisoner was discharged on the ground that the information sent by the demanding governor was "only a verified accusation by the prosecuting attorney, and is barren of any oath as to the matters contained therein; neither ... [did] it show any endorsement thereon of the names of the prosecuting witnesses." 122 Colo. at 477-78, 223 P.2d at 623. See also, e.g., In re Kjeldsen, 39 Misc. 2d 128, 240 N.Y.S.2d 71 (1963); In re Fritz, 137 N.J. Eq. 185, 44 A.2d 414 (1945).

10. See, e.g., Cassis v. Fair, 126 W. Va. 557, 29 S.E.2d 245 (1944) ; Ex parte Hubbard, 201 N.C. 472,160 S.E. 569 (1931).

11. The exact charge against the defendant must be specified. See, e.g., People ex rel. Ritholz v. Sain, 24 Ill. 2d 168, 180 N.E.2d 464 (1962). There the defendant was con- 
the demanding state's request is initially determined by the governor of the asylum state, usually after a hearing. ${ }^{12}$ If the governor decides to extradite, the accused has recourse to habeas corpus for judicial review of this determination $;^{13}$ this review has often led to denial of extradition because of some flaw in the request from the demanding state. ${ }^{14}$ While it is true that an indeterminate amount of official kidnapping occurs, ${ }^{15}$ police compliance with statutory procedures seems the normal course of behavior. ${ }^{16}$

In contrast, the bondsman is largely immune from judicial control; his power over an accused may exceed the power of the state. As a consequence, he plays a singularly significant role in the pre-trial period. Clothed with the powers of a peace officer armed with a warrant, ${ }^{17}$ the bondsman may seize the accused in a foreign jurisdiction without the slightest compliance with extradition requirements in the foreign jurisdiction. ${ }^{18}$ The bondsman is often able,

victed, sentenced and fined by a Michigan trial court for the crime of bribing public officers. Conviction and sentence were affirmed upon appeal, but the defendant, who had been released on bail pending outcome of the appeal, fled into Illinois, and subsequently failed to surrender.

12. See Comment, Interstate Rendition: Executive Practices and the Effects of Discretion, 66 YALE L.J. 97, 100-03 (1956). On receipt of the demand, the governor of the asylum state determines whether they conform to the requirements of the federal and state statutes. If conformity is established, an extradition warrant for the arrest of the fugitive is issued. The accused has no legal right to an executive hearing, but upon timely request most governors will grant an executive hearing, and some do so as a matter of course. Usually an administrative official, perhaps from the attorney general's office, presides over the hearing, in which the accused has the burden of contravening the allegations of the requisition documents. The governor may grant or deny rendition upon receiving the hearing examiner's report. Exercise of the governor's discretion to refuse rendition is not subject to judicial review; his is a "moral duty," unenforceable by the demanding state. The governor may refuse rendition on the grounds of, inter alia, formal defects in the requisition papers, failure to allege facts constituting a crime under the laws of the demanding state, absence from the demanding state at the time that the crime was committed, or absence of any factual substantiation of the charge. Ibid.

13. Ibid.

14. Besides the cases cited in notes 19-22 supra, see, e.g., People ex rel. Fuller v. Chaufty, 27 Misc. 2d 1074, 213 N.Y.S.2d 841 (1961); McGahagin v. State, 41 Ala. App. 236, 131 So. $2 \mathrm{~d} 425$ (1961); Ex parte Burns, 167 Tex. Crim. 533, 322 S.W.2d 289 (1959); United States ex rel. Argento v. Jacobs, 176 F. Supp. 877 (N.D. Ohio 1959) ; Brown v. Grimes, 214 Ga. 388, 104 S.E.2d 907 (1958); In re McMeans, 146 N.E.2d 159 (Ohio Com. P1. 1957).

15. See Note, Illegal Abductions by State Police: Sanctions for Evasion of Extradition Statutes, 61 Y ALE L.J. 445, 448 (1952).

16. General compliance may be inferred from the rather sizeable volume of reported litigation on technical points of extradition procedure. It is impossible to discern any signs of judicial disillusion with the extradition laws arising from police circumvention.

17. See Ex parte Chance, 2 F. Supp. 393 (N.D. Tex. 1933).

18. In re Von Der Ahe, 85 F. 959 (C.C.W.D. Pa. 1898). A citizen of Missouri had returned there after jumping bail set in Pennsylvania, and had been forcibly brought back to Pennsylvania by his bondsman to satisfy a judgment entered against him for malicious prosecution. The court recognized no difference between the power of bondsmen in civil, as opposed to criminal actions and, in fact, purported to follow a leading criminal case. The court distinguished between the bondsman's power and that of a state seeking extradition, as follows: 
as a matter of courtesy, to enlist the assistance of officials in the asylum state in apprehending the accused or in keeping him in custody for a brief time

Of late years we have grown so accustomed to the proceedings by requisition that we have come to regard it as the only means by which a person can be arrested and moved from one state to another. An examination of the authorities, state and federal, shows, however, that under certain circumstances, bail bondsmen have the right to arrest their principals, wherever they find them, and remove them to the Id. at 960 .

forum from which they have been released ....

This doctrine was reiterated in Golla v. State, 50 Del. 497, 135 A.2d 137 (1957). There the defendan' had been released, after arrest in Delaware for assault, on $\$ 2500$ bail. While still on bail he went to Pennsylvania, where he was arrested by Pennsylvania authorities for violation of a Pennsylvania parole, and was there jailed. Thereafter, two Wilmington policemen, acting as agents for the Delaware bondsman, appeared at the Pennsylvania prison and, with the Pennsylvania authorities' consent, and upon a showing of a bail relation, took the prisoner into custody and returned him to Delaware. On appeal from his Delaware conviction, the prisoner contended that he was improperly brought to Delaware from Pennsylvania, since he neither waived extradition, nor was any extradition sought by the state of Delaware. His appeal failed, the Delaware Supreme Court holding that since the prisoner was taken into custody by agents of the bondsman, acting under the authority of the bail piece, and not by ary action of the state of Delaware, no extradition was required. The court said:

In our opinion no extradition was necessary since the prisoner was taken into custody by the agents of his bondsman acting under the authority of a bail piece. It seems to be well established that a bondsman seeking to deliver to custody the person for whom he is responsible, and who has obtained a bail piece may pursue the fugitive to any place within the jurisdictional limits of the United States, and take him into custody.

50 Del. at 501,135 A.2d at 139 . The court further remarked that the defendant's contention was "wholly devoid of any merit and could have been disposed of summarily, in order to demonstrate its lack of even a fairly debatable point of argument." Ibid. See also United States v. Trunko, 189 F. Supp. 559, 563, 565 (E.D. Ark. 1960) ; Fitzpatrick v. Williams, 46 F.2d 40 (5th Cir. 1931); Ex parte Chance, 2 F. Supp. 393 (N.D. Tex. 1933) (dictum) ; Ex parte Salinger, 288 F. 752, 755 (2d Cir. 1923) (dictum); State v. Lingerfelt, 109 N.C. 775, 14 S.E. 75 (1891); Note, 66 DICK. L. REv. 101 (1961).

In the recent case of United States v. Trunko, supra, Trunko, an employee of the bonding company, was dispatched in pursuit.

He elected to make his arrest (in Ark.) in the hours of darkness. When the door was opened to his knock, he burst his way into the presence of a law-abiding peaceable old man. He rudely entered a bedroom occupied by a man, his wife, and baby, flashing a light in the eyes of the sleeping object of his search ... and placed [the principal] under arrest, thereafter hastening from the house, placing him in an automobile, and handcuffing him as though he were a dangerous criminal. After so doing, the [bondsman] . . . drove away with [the principal, to Ohiol at a terrific rate of speed, ignoring the pleas and protests of their prisoner's wife. All Id. at 565 . of this was done to secure a remission of a $\$ 500$ bond.

The United States sought, in an Arkansas District Court, a criminal conviction under a federal civil rights statute [18 U.S.C. $\$ 242$ (1958)], alleging that Trunko, acting under color of state law, had deprived the accused of his constitutional right to orderly transfer between states under the federal extradition laws. Although the court in Trunko expressed in general terms its disapproval of the pursuer's conduct (189 F. Supp. at 561, 564), it stated that there would be nothing illegal in a private bondsman's utilization of such methods of pursuit, capture and removal. Id. at 563,565 . 
before the bondsman takes him to the accusing jurisdiction. ${ }^{19}$ All the bondsman need do to obtain this assistance is to show asylum state officials documentary evidence of the existence of the bond relationship between himself and the accused. ${ }^{20}$ This document, called a "bail piece" or "mittimus" order, is obtained by the bondsman from an official, usually a judge, ${ }^{21}$ in the accusing jurisdiction. Normally, it recites only the name of the accused, the formal charge, the date at which the accused was to appear for trial, and the existence of the bond relationship. ${ }^{22}$ By establishing the bond relationship, the bail piece enables the bondsman to reduce the principal to his custody at any time and place during the relationship, and to return him forthwith to the court where bail was given. ${ }^{23}$ No hearing need ever occur. Despite the apparent frequency of interstate pursuit of criminals by bondsmen, the iniquities of an "extraditing" bondsman rarely find their way into opinions. For one thing, it is well established that illegal seizure to bring an accused within an accusing state is no defense to that state's jurisdiction at a subsequent criminal trial $;^{24}$ an accused wishing to challenge at trial the bondsman's action in removing him from a foreign jurisdiction would at once be met with this doctrine. In addition, there appear to be few private law remedies for illegal removal. No recent case has been reported in which a principal has sued, much less collected a judgment, for false arrest or other tort recovery against "extraditing" bondsmen or cooperating asylum state officials. ${ }^{25}$ Finally, there is no practical

19. "It had been the original plan of . . . [the bondsman's agents] to lodge ... [the principal] in jail temporarily in Little Rock while they rested from their long drive from Phoenix, Arizona, to Arkansas, and then to resume their trip." United States v. Trunko, 189 F. Supp. 559, 562 (1960). "He could have contacted the Sheriff of White County and made his mission known and obtained assistance or support if he felt such to be necessary." Id. at 565. Interviews with bondsmen and officials indicate that these practices are widely carried on.

20. See United States v. Burl, 67 F. Supp. 583, 586 (E.D. Ill. 1946) ; Restatenient, ToRTs $\$ 120$ (b), and comment. Compare In re Von Der Ahe, 85 F. 959, 960 (C.C.W.D. Pa. 1898) (". . . a bail piece is not the authority for the arrest, but is simply evidence of the relation between the parties."), with Golla v. State, 135 A.2d 137, 139 (1957).

21. See, e.g., Pa. Stat. Anv. tit. 19, §53 (1930) ; Conn. Gen. Stat. $52-319$ (Supp. 1962). The latter statute is assumed to authorize issuance of a bail piece in the case of actual as well as "intending" bail-jumpers.

22. See, e.g., mittimus used in Connecticut Circuit Courts, CCT 10 Rev. 7/61, clegpub.

23. See note 29 supra.

24. Frisbie v. Collins, 342 U.S. 519 (1951) ; Ker v. Illinois, 119 U.S. 436, 444 (1886).

25. For a brief discussion of the doctrines which hinder tort recovery against officers, see Goldstein, The State and the Accused: Balance of Advantage in Criminal Procedure, 69 Yale L.J. 1149, 1165 n.48 (1960). If convicted, the defendant may be in no position to recover against either police or bondsman:

[W] here conviction is followed by imprisonment, the chances that the potential plaintiff will be able to prosecute his action are slim indeed. Even if his conviction does not destroy his right of action, the obstacles of prosecuting a civil suit from a prison cell are almost insuperable, and the Supreme Court was probably wrong when' it assumed in Ker $v$. Illinois that the convicted and imprisoned defendant could have his private action. 
access to courts in the asylum state; a bondsman apprehending an accused in a foreign jurisdiction need not surrender him to the custody of an asylum state. The general practice is that, even where asylum state officials cooperate with the bondsman by keeping the accused in prison temporarily, the accused is never presented before a magistrate. ${ }^{26}$ Thus, the accused is rarely given an opportunity to secure legal counsel while he is temporarily detained in the asylum state, and is rarely informed of his possible rights against removal to another jurisdiction.

There is always the possibility that the bondsman can justify his extraordinary powers by distinguishing state extradition proceedings on some "policy" basis. Thus, it may be argued that the extradition laws are designed solely to preserve harmony between asylum and demanding states, and that the bail bondsman is a private agent whose activities can in no way constitute a violation of the asylum state's sovereignty; the inconsistency would then be defensible. Both strands of the argument are of questionable validity. The professional bail bondsman's important and continuing role in the criminal processes of the demanding state suggests that the argument that he is engaged in "private" as opposed to "state" action exalts form over substance. 27 Particularly in the case when apprehension and return of a fugitive accused is at issue, the bondsman's role as de facto agent of the demanding state emerges with clarity; indeed, pursuing bondsmen are often accompanied by "off-duty" policemen from the demanding jurisdiction. ${ }^{28}$ The end result of the bondsman's efforts - exposure of the accused to criminal sanctions in the demanding jurisdiction - is identical with the goal of extradition proceedings; bondsmen are privileged to achieve such results by a status created by the state explicitly to serve such functions. Given the close involvement of private bondsmen in the effectuation of the demanding state's criminal law administration, it is difficult to see how the asylum state's sovereignty is less offended by the "private" than by the "official" method of removal. Second, although the extradition laws are intended to preserve interstate harmony, ${ }^{20}$ both by requiring formal demand and by restricting severely the asylum state's inquiry upon the tendering of a demand, federal provisions also reflect a major counterprinciple - the protection of individuals within the asylum jurisdiction from the expense and inconvenience of being transported against their will to foreign jurisdictions, when the accusation of criminal conduct is patent-

See also Foote, Tort Rentedies for Police Violations of Individual Rights, 39 MrNN. L. REv. 493, 507 (1955). Moreover, there are economic obstacles to prosecuting a civil action, even for defendants who are not convicted. Cf. Hall, The Law of Arrest in Relation to Contcmporary Social Problems, 3 U. CHI. L. REv. 345, 352 (1936) (actions against sureties on official bonds). The equities would seem to run strongly against the bail-jumper in an action against his bondsman. Cf. Foote, supra at 500.

26. Interviews with bondsmen and officials.

27. Cf. Note, 70 YALE L.J. 966, 972 (1961).

28. Interviews with bondsmen and officials. And see Golla v. State, 50 Del. 497, 135 A.2d 137 (1957).

29. See 2 MOORE, Extradition $\S \S 521-22$, at 826-31 (1891). 
ly frivolous or mistaken. ${ }^{30}$ Recognition of this policy against interstate transfer on frivolous or malicious grounds was articulated as early as 1793 , when the original federal extradition statute was enacted $;^{31}$ courts have also noted

30. The generally protective character of the extradition requirements is expressed in United States v. Meyering, 75 F.2d 716 (7th Cir. 1934), as follows:

The [federal] statute is one involving the substantial rights of citizens, and its essential elements must be strictly followed. Only by faithfully following the provision of the statute may a person be lawfully deprived of his liberty and extradited from an asylum state to another state, there to be tried for the commission of a crime. The alleged fugitive has a right not to be imprisoned or dealt with by the states in disregard of those safeguards provided by the Constitution and statutes of the United States.

Id. at 717. See Note, Illegal Abductions by State Police: Sanctions for Evasion of Extradition Statutes, 61 YALE L.J. 445, 448 (1952).

An examination of the federal rule of criminal procedure dealing with the removal of criminal defendants from one federal district to another for trial in a federal court may help to illumine certain aspects of the policy underlying extradition laws. Under FED. R. CRIM. Proc. 40, the procedure which is followed depends on whether the demand for removal is based upon an indictment or upon an information and complaint. If it is based upon information and complaint, proof of reasonable cause to believe the defendant guilty must be adduced. If it is based upon indictment, proof of identity coupled with a certified copy of the indictment will suffice, as the indictment will be exclusive proof of probable cause. A similar distinction appears in section 3 of the UNIFoRM CRIMINAL Extradrtion Acr. Alexander Holtzoff, the Secretary of the Advisory Committee on Federal Rules of Criminal Procedure in 1943 when Rule 40 was adopted, explains (3 F.R.D. 445, 451-52) that the distinction reflects the fact that in the case of an indictment, the grand jury, an independent body, "which is an arm of the court," has already found probable cause. The facts found must, nevertheless, constitute an offense under federal law. In the case of a complaint or information, no such determination has been made and, therefore, separate proof of reasonable cause is required. In either case, the defendant is entitled to a judicial hearing in the asylum district. The revisers recognized that

theoretically, it seems anomalous and illogical that although the entire United States is a single jurisdiction from the standpoint of the Federal Government, nevertheless, a proceeding akin to extradition should be required to enable a delivery of a fugitive from one territorial subdivision to another.

Id. at 450 .

But it was felt that,

on the other hand, as a practical matter, in view of the long distances that are at times involved, some supervision and restrictions seem desirable on the transportation of an accused person from one part of the country to another.

Ibid. Thus, extradition-like provisions were retained, in order to protect defendants against removal on insubstantial grounds, in cases where the distance involved was greater than 100 miles. Rule 40 (a). The point of this reference to the removal rules is that the advisory committee, Congress and the Supreme Court, faced with the task of codifying and streamlining the rules which had grown up under the extremely general removal statute, 18 U.S.C. former $\$ 591$, now $\$ 3041$, adopted an extradition-type procedure whose restrictions and hearing privileges can be justified only in terms of a policy of protecting defendants against improvident transfer. This suggests that similar provisions in the extradition laws may be defended on similar grounds, and that their social utility cannot be expressed solely in terms of the policies of interstate harmony.

31. This statute supplemented U.S. CoNsT. art. IV, $\S 2$, by specifying the authority upon which demand was to be made, the form of the demand and the methods to be used 
the importance of extradition statutes as procedural safeguards of the rights of the accused..$^{32}$

Since the shining knight of "policy" does not avail the bondsman, he may attempt to justify his technique on mundane practical considerations. What of the spectre of increased forfeitures? If bail-jumpers could skip the jurisdiction without fear of a pursuing bondsman, the business risk would be increased and the bonding business depressed and discouraged. The argument assumes that the state would not permit bondsmen to shift the increased risk of loss to accused seeking to make bail, an assumption perhaps reasonable in view of the present widespread concern over the inability of many defendants to meet present premium and collateral requirements. ${ }^{33}$ Granting the assumption, it is probable that application of the extradition law to the bondsman would not significantly alter his forfeiture rate. Under the extradition laws as presently administered, extradition is, in percentage terms, only rarely refused; in instances where the requisition papers are found defective, the demanding state may, at the habeas corpus hearing, be able successfully to amend its request by correcting inconsistencies or by furnishing more information. ${ }^{34}$ It seems reasonable to suppose that the ratio of forfeitures arising from refused extradition to all other forfeitures would be very slight. ${ }^{35}$ Hence,

in recovering the fugitive. 18 U.S.C. $\S 3182$ (1958). But the necessity for providing effective machinery was not the only policy consideration deemed important by Congress. In an opinion which greatly influenced the final form of the statute, Attorney General Randolph, discussing the constitutional requirement that the person be "charged," deemed it "sufficiently technical to exclude any wanton or unauthorized accusation from becoming the basis of the demand." 2 Moore, Extradition $\$ 532$, at 842 (1891). Also, proof of fugitive status was thought necessary, for otherwise, "the most innocent citizen might be carried in chains from his own state to another." 2 Moore, Extradition $\$ 532$, at 843. Thus, there seems to have been some consideration of certain procedural risks inherent in the extradition provision. This concern was reflected in the formal requirements of the 1793 statute, which, in turn, are carried over into section 3 of the UNIFORM ACT.

32. See, e.g., Henry v. McArthur, 122 Colo. 474, 223 P.2d 621 (1950), where the court discharged the prisoner on the ground set forth in note 20 supra, and stated:

[T] allow the removal of a Colorado citizen to another state upon such a showing would sanction the possibility of designing individuals, in their enmity, to make false accusations against a person and bring about their wrongful arrest and removal from the state.

122 Colo. at 479, 223 P.2d at 623. See also Ex parte Hart, 63 F. 249, 259 (4th Cir. 1894).

33. See Report of the Attorney General's Committee on Poverty and the Administration of Federal Crrminal Justice 66-68 (1963); Comment, A Study of the Administration of Bail in New York City, 106 U. PA. L. REv. 693, 707 (1958) ; Foote, Compelling Appearance in Court: Administration of Bail in Philadelphia, 102 U. PA. L. Rev. 1031, 1032 (1954).

34. See People v. Sain, 24 I1l. 2d 168, 180 N.E.2d 464 (1962) ; Hackler v. Lohman, 17 Ill. 2d 78, 88-89, 160 N.E.2d 792, 799 (1959).

35. Since 1936, there have been approximately 100 reported cases - most of them unfavorable to bondsmen - dealing with remission of forfeitures. In the great majority of the cases in which remission was denied, courts emphasized either that the default of the principal was "willful," or that the police retrieved the fugitive without assistance from the bondsman, or simply that the appearance of the accused for trial either never 
the increase in the rate of forfeitures would be slight. ${ }^{36}$

The bondsmen may justifiably complain, however, because a more elaborate system of extradition would add to the costs he now incurs in ensuring removal through his present, primitive extraterritorial arrest procedure. The courts of the demanding state, in the exercise of their broad discretion to resolve questions relating to the forfeiture of bail bonds in the manner "required by justice,"37 might impose such additional costs upon the bondsman in one of three ways. If the bondsman has already paid a forfeiture, and the demanding state makes the initial expenditures necessitated by extradition, the amount of those expenditures may be deducted from the amount of the forfeiture remitted once the accused has been returned for trial. ${ }^{38} \mathrm{Or}$, if the bondsman has not been required to pay the forfeiture before the time when he surrenders the accused for extradition, the court in the demanding jurisdiction may require him to pay a forfeiture - in the nature of a reimbursement - equal to the expenses incurred by the demanding state in financing the accused's extradition. ${ }^{39}$ Finally, if the bondsman himself has made out-of-pocket expenditures in order to bring about removal by extradition, the burden would rest upon him if the courts of the demanding state refused to entertain claims for reimbursement of the bondsman's expenses. The result of throwing this financial burden upon the bondsman might be a serious undermining of the bondsman's elan as a pursuit agent. ${ }^{40}$ Yet this burden could readily be avoided

occurred or was delayed beyond a statutory time limit. Remission occasionally has been denied when the default resulted from the arrest and confinement of the principal in another state for a different offense. Compared with these causes of forfeitures, refusal to extradite (under the hypothesized extension of the extradition laws) would be of little importance.

36. Note, also, that a very small percentage of all principals jump bail. See Foote, Administration of Bail in Philadelphia, 102 U. PA. L. Rev. 1031, 1063 (1954). And in the event that the authorities in the bail jurisdiction declined to seek extradition of a defendant located and held by a bondsman in another state, the bondsman might successfully recoup a forfeiture under a traditional doctrine that the surety cannot be held liable where his inability to produce the principal results from the interference by the state in which bail was given. See $I n$ re Beavers, 131 F. 366 (C.C.E.D. N.Y. 1904); Bowling v. Commonwealth, 123 Va. 340, 96 S.E. 739 (1918).

37. See generally State v. Liakas, 165 Neb. 503, 86 N.W.2d 373 (1957) ; Annotation, 4 A.L.R.2d 440. See also Fed. R. Crrar. P. 46 (f) (2); Oнio Rev. Code Ann. $\$ 2937.39$ (Supp. 1963).

38. Cf. United States v. Smith, 5 F.R.D. 274 (W.D. Ky.) ; Weinstein v. United States, 124 Ct. Cl. 559 (1953) ; Commonwealth v. Yavelberg, 48 Pa. D. \& C. 583 (1944).

39. Cf. Allison v. People, 132 Colo. 156, 286 P.2d 1102 (1955) ; State v. Wright, 193 Okla. 383, 143 P.2d 801 (1943).

40. The digests contain a considerable number of cases in which the bondsman had vigorously pursued the defendant, suggesting that bondsmen remain highly motivated to avoid or recoup forfeitures by such means. See, e.g., People v. Manufacturers Cas. Ins. Co., 208 Misc. 504, 144 N.Y.S.2d 282 (1955); United States v. Legg, 157 F.2d 990 (4th Cir. 1948). Interviews with bondsmen reveal that some bondsmen pursue bail-jumpers, even where adequate security has been given by a third-party indemnitor, in order to maintain a reputation for relentless pursuit as a general psychological deterrent to flight. 
through an equitable administration of forfeiture policy by the courts of the demanding state. ${ }^{41}$ Where the bondsman is successful in reducing the accused to custody, justice seems to require that forfeitures be remitted in full, without a deduction for extradition expenses incurred by the state, and that no reimbursement, in the form of a partial forfeiture, be assessed against the bondsman. On the contrary, the court might be expected to entertain quasicontract actions by the bondsman - who after all has placed the defendant within the state's grasp - against the demanding state for reimbursement of that part of the bondsman's out-of-pocket costs which is attributable to the imposition of extradition requirements upon him.

Although opposition to procedural protections for the accused pursued by his bondsman cannot be sustained on grounds of severe financial impact on bondsmen, it is nevertheless desirable that additional costs, delays and procedural complications should not exceed that level which is necessary for the protection of the accused's rights and the asylum state's interests. Thus it may be argued that, while extradition protections should be afforded the alleged bail-jumper in the asylum state, they should be limited to a hearing on questions relating to the identity of the accused and the existence of the bail relationship. Certification by the demanding state of the bond bearing the defendant's signature, and of the fingerprints presumably taken at the time of original arrest would require no more than a summary hearing, yet insure against cases of mistaken identity. ${ }^{42}$ The hearing, however narrow, would also provide minimum satisfaction of the asylum state's interest in protecting its sovereignty and discouraging self-help measures which may produce either breaches of the peace or irremediable injustice. By allowing a bailed accused some breathing space in which to prepare to challenge, in an orderly, open court proceeding, the bondsman's right to carry him out of the jurisdiction, and thus shedding light on bondsman's activities, such a hearing might also tend to discourage bondsmen from employing brutal methods in the course of arrest and removal. ${ }^{43}$

In one city, enjoying a low forfeiture rate, a court clerk suggested that the low rate was ... due, perhaps, to the fact that personal bondsmen in our county are a very aggressive group and relentlessly pursue the defendant who skips bail on which they are surety and bring them back in very many instances. We have had examples where they have gone out of the country in order to effect the production of a person who had skipped bail. This hard attitude on the part of some of these sureties has put the fear of God into a lot of defendants who know what to expect in the event that they skip bail; so we do not have any particular problem in this regard.

Letter from Clerk of District Court, Douglas County, Omaha, Neb., June 24, 1953, quoted in Foote, Compelling Appearance in Court: Administration of Bail in Philadelphia, 102 U. PA. L. Rev. 1031, 1087 (1954). Professor Foote, however, remains unconvinced of the efficiency of "private law-enforcement" in this area. Ibid.

41. See note 37 supra and accompanying text.

42. Questions of identity have occasionally arisen in extradition proceedings. See, e.g., Commonwealth ex rel. Dronsfield v. Hohn, 390 Pa. 434, 135 A.2d 757 (1957); Cook v. Rodgers, 215 Ind. 500, 20 N.E.2d 933 (1939); Note, 32 Colun. L. Rev. 1069 (1932).

43. See United States v. Trunko, discussed in note 18 supra. 
Two assumptions underlie a suggestion to supplement current bondsmen's practices merely by requiring a limited hearing in the asylum state. The first assumption is that the publicity of a hearing will temper the bondsmen's conduct. There is some truth to this; the institution of bail is under such intensive attack ${ }^{44}$ that the embattled bondsman will act carefully before supplying more ammunition for his critics. However, to permit bondsmen to continue to make their own arrests in the asylum jurisdiction is to tempt the bondsman to violate any post-arrest surrender provisions which might delay or hinder the bondsman in removing the defendant - now within his actual physical custody. The temptation would be emphasized if the statute requiring such a hearing followed the model of the Uniform Fresh Pursuit Act, ${ }^{45}$ which imposes analogous requirements on police officers of a foreign jurisdiction who enter the "asylum" state in hot pursuit of an absconding accused, but fails to provide any sanction for violation of its requirements. It may be wiser, therefore, to follow a recent California statute, 48 and deprive the bondsman of his right of arrest in the asylum state by requiring him to apply to a magistrate for a warrant directing that the alleged fugitive be arrested by officers of the asylum jurisdiction and presented before a magistrate to be informed of his right to counsel. Violation of the statute by a bondsman is a misdemeanor; even if the more limited approach of a right to a hearing were adopted, an enforcement provision imposing such a penalty would seem requisite.

The second assumption behind the suggestion of a hearing limited to proof of identity and the existence of the bail relationship is that such a hearing provides sufficient safeguards. Removal in such cases need not be conditioned on a finding of fugitive status, or of factual substantiality in the charge against the accused, it may be thought, because such substantiality and status may be assumed from the fact that the accused could not have been arrested and granted bail, without a finding of probable cause by officials of the demanding state. ${ }^{47}$ But extradition case-law uniformly evidences a feeling that such an assumption cannot properly be made. Courts have not discriminated against bail-jumpers or other post-arrest escapees in determining the availability of extradition safeguards. Indeed, there is some judicial support for the view that a bail-jumper may seek habeas corpus on the ground that he was not in the

44. See Carbo v. United States, 82 Sup. Ct. 662 (1962) (Douglas, J., determining application for bail pending appeal under F. R. Crim. P. 46); Pannell v. United States, 320 F.2d 698, 699, 702 (D.C. Cir. 1963) (concurring opinions of Wright and Bazelon, JJ.); Note, Bail: An Ancient Practice Reexamined, 70 Yal. L.J. 966, 971 (1961); Report of the Third February 1954 Grand Jury of New York County, reprinted in 17 Law. Guild Rev. 149 (1957). See also Report of the Attorney General's Conimittee on Poverty and the Admististration of Federal Criminal Justice 66-67 (1963).

45. See California version, Calif. Penal Code $\$ \$ 852-852.4$ (1956).

46. Calif. Penal Code 847.5 (1963 Supp.).

47. See Goldstein, The State and the Accused: Balance of Advantage in Criminal Procedure, 69 YALE L.J. 1149, 1164 (1960). 
demanding state at the time of crime. ${ }^{48}$ Legislative choices reflected in statutory provisions also call the assumption into question. In its bail extradition statute, California has rejected the notion that asylum state inquiry into fugitive status is superfluous in the case of the bail-jumper, and requires a showing that the accused was in the demanding state at the time of the alleged crime and that he is presently sought to answer for it. ${ }^{49}$ Section 3 of the Uniform Criminal Extradition Act expressly requires that, in cases where a defendant has jumped bail pending appeal or commitment after conviction, the demand must include, besides a copy of the judgment of conviction or sentence, an allegation that the defendant has broken the terms of his bail together with a separate allegation that the accused was in the demanding state at the time of the alleged crime. ${ }^{50}$ Such a separate allegation would be unnecessary if the bail relation itself constituted sufficient proof of fugitive status.

If fugitive status cannot be lightly inferred from the bail relationship, neither can factual substantiation of the charges brought against the accused. The normal extradition case would seem to require more of the demanding state than production of the bail piece. The courts have indicated, in cases of flight before arrest, that demanding papers accompanied only by a warrant for the defendant's arrest, are insufficient to justify rendition, ${ }^{51}$ despite the fact that such a warrant could not have been issued without a finding of probable cause based on an affidavit of a complaining witness. If such a warrant is insufficient to justify rendition of an accused who flees before arrest, such a warrant, standing by itself, must be insufficient to justify rendition of a post-arrest fugitive. It would be curious if the fact of bail-setting was used as a substitute for factual substantiation in these circumstances. In the case of such a fugitive who flees before preliminary hearing, there has been no finding of probable cause supplementing or reviewing the initial determination to issue the warrant, even if bail has been granted. Nor can it be presumed, as a general proposition, that post-arrest fugitives have already had a sufficient opportunity to test the substantiality of the charge while in the demanding jurisdiction, since, at the police stage of the proceeding, many defendants either cannot afford counsel or have not been made sufficiently aware of their rights. ${ }^{52}$ Thus it would be unreasonable for courts to hold that defendants who flee after arrest

48. See Kay v. State, 34 Ala. App. 8, 37 So. 2d 525 (1948).

49. See note 46 supra. It is assumed that the term "fugitive" is used in this statute in the same sense as it is used in the federal and state extradition laws, in which a fugitive is one who, having committed or been charged with a crime in one state, has left its jurisdiction and is found within the territory of another state when it is sought to subject him to the criminal process of the former state. Ex parte Riccardi, 69 Ariz. 180, 203 P.2d 627 (1949).

50. 9 U.L.A. 274 (1957).

51. See Coats v. Sain, 24 Ill. 2d 248, 181 N.E.2d 179 (1962); Hanowski v. Sullivan, 41 So. 2d 338 (Sup. Ct. Fla. 1949); In re Fritz, 137 N.J. Eq. 185, 44 A.2d 414 (1945).

52. See Goldstein, The State and the Accused: Balance of Advantage in Criminal Procedure, 69 YALE L.J. 1149, 1165 (1960). 
but before preliminary hearing are less entitled than pre-arrest fugitives to a showing of factual substantiality based on affidavits or indictments included in the demanding papers. ${ }^{53}$

It follows that bailed accused, and not merely pre-arrest fugitives, are entitled to a full extradition-type hearing, in which the demanding state is obliged to establish substantiality and fugitive status by affidavits or indictment in support of requisition. Because the bondsman's methods have long gone unchallenged, such reforms have the appearance of a substantial innovation. The few precedents in this area uniformly hold that the bail piece provides sufficient authorization for arrest and removal of the defendant from the jurisdiction by his bondsman..$^{54}$ Courts, even if they could require a hearing, could not effectively require that the bondsman surrender his principal to the authorities of the demanding state in order that such a hearing might take place. Nor, for reasons stated above, is the bailed fugitive in a position to initiate judicial intervention. ${ }^{55}$ The problem thus seems one for the legislature. If the legislative response to the problem is to include suspension of the bondsman's right of arrest, the California statute ${ }^{56}$ might serve as an appropriate model. If not, some lesser degree of assurance of a judicial hearing may yet be afforded by legislation similar to the Uniform Fresh Pursuit Act. ${ }^{57}$ In either event, the legislation should provide criminal sanctions for violation of its requirements. In addition to the controls imposed on the bondsman's arrest activities, the legislature must determine, as a separate issue, the scope of the hearing to be provided. Although the California statute provides a hearing which inquires beyond mere questions of identity and proof of the bond relationship, the issues to be determined do not include that of factual substantiation. Since bail-jumpers have equities - substantially equal to the equities of other accuseds ${ }^{58}$ - in an opportunity to raise this issue while still in the asylum state, the new legislation should expressly require the issue to be heard.

53. Furthermore, the situation is not much different after the preliminary hearing. It has been said that, in practical effect... the preliminary hearing in the United States does not add Id. at 1168 . significantly to the police evidentiary screen which has preceded it.

[S] ince defense counsel is usually either not present, or insufficiently informed to play his role properly, it ordinarily falls to the magistrate, almost alone, to test the sufficiency of the evidence .... Yet, most magistrates are either unskilled, or too busy, or too closely linked with police or prosecutor, or insufficiently mindful of the "judicial" nature of their role to perform this function adequately. And the sole review of the sufficiency of the evidence before them is the limited one afforded by habeas corpus which looks only for some "legally competent evidence" to support the order committing the accused for trial.

Id. at 1167.

54. See note 18 supra.

55. See text accompanying notes 25-26 supra.

56. See note 46 supra.

57. See note 45 supra.

58. See text accompanying notes $52-54$ supra. 
Of course, there remains the possibility that in taking cognizance of the problems discussed in this Note, a legislature might view the irregularities and circumventions of extradition laws associated with removal by bondsmen as a "last straw" justifying a critical reappraisal of all facets of the bondsman's contributions to criminal administration. For years, the bondsman has been roundly accused of a wide variety of corrupt practices ${ }^{59}$ and criticized on the ground that a bondsman's refusal to become surety for certain defendants may operate to overrule a magistrate's determination that the defendant ought to be released if he is financially able to post bail at a certain amount. ${ }^{60}$ However, there is at present no significant movement in the direction of abolishing the criminal bail bond business either by direct or indirect means. Indeed, any such movement would in some way have to dispose of the not implausible argument that the bondsman's vigorous pursuit activities effectively supplement police efforts to retrieve fugitives and thus have some social utility worth preserving. ${ }^{61}$ Throughout the foregoing discussion, the assumption has been made that the bonding business will continue to flourish as an integral element of American criminal administration and that the problems raised by the bondsman's extraterritorial activities will continue to exist until relieved by legislative action requiring some form of judicial intervention in the asylum state.

59. See, c.g., Report of the Third February 1954 Grand JuRy of New York County, reprinted in 17 Law. Gumd Rev. 149 (1957); Moley, Our Criminal Courts 43-56 (1930).

60. See, c.g., Pannell v. United States, 320 F.2d 689, 699, 702 (D.C. Cir. 1963) (concurring opinions of Wright and Bazelon, JJ.); Note, 70 YALE L.J. 966, 971 (1961).

61. See note 40 supra. 